\title{
PENINGKATAN KEMAMPUAN MENYUSUN SOAL DENGAN METODE PENDAMPINGAN BERPOLA SP3R PADA GURU SDN SEPANYUL KECAMATAN GUDO KABUPATEN JOMBANG TAHUN 2018
}

\author{
Dedi Kasiono \\ Sekolah Dasar Negeri Sepanyul Kec. Gudo Kabupaten Jombang \\ Email: bharataprima@gmail.com
}

\begin{abstract}
Abstrak: Tujuan penelitian ini adalah (1) memperoleh gambaran efektifitas penggunaan teknik pendampingan berpola SP3R dalam penyusunan soal, (2) memperoleh gambaran peningkatan kemampuan guru dalam menyusun soal dengam teknik pendampingan berpola $\mathrm{SP}_{3} \mathrm{R}$. Penelitian ini menggunakan alur penelitian rancangan model Kemmis yang terdiri atas empat langkah, yakni: perencanaan, pelaksanaan, observasi dan refleksi. Dalam pelakanaannya, peneliti mengintegrasikan kegiatan pendampingan pola $\mathrm{SP}_{3} \mathrm{R}$ pada tahap pelaksanaan, dan menjadi sebuah system terintegrasi.Hasil penelitian adalah (1) penggunaan teknik pendampingan berpola SP3R sangat efektif untuk meningkatkan kemampuan guru dalam menyusun soal. (2) kemampuan guru dalam menyusun soal mengalami peningkatan dimana pada pra siklus kemampuan guru dalam menyusun soal berada pada angka 67 menjadi 83 pada siklus I dan naik menjadi 91 pada siklus II. Kesimpulan pada penelitian ini adalah teknik pendampingan dengan pola SP3R sangat efektif dan dapat meningkatkan kemampuan guru dalam menyusun soal.
\end{abstract}

Kata Kunci: kemampuan menulis soal, guru, pendampingan berpola SP3R.

Abstract: The purpose of this study is (1) to get an idea of the effectiveness of the use of SP3R patterned assistance techniques in the preparation of questions, (2) to get a picture of increasing the ability of teachers in compiling questions with technical assistance patterned SP3R. This study uses a research flow design Kemmis model consisting of four steps, namely: planning, implementation, observation and reflection. In their implementation, the researcher integrated the SP3R pattern of assistance activities at the implementation stage, and became an integrated system. The results of the study are (1) the use of technical assistance with the pattern of SP3R is very effective to improve the ability of teachers to arrange questions. (2) the ability of the teacher in compiling questions has increased where in the pre-cycle of the teacher's ability to arrange questions the number is 67 to 83 in cycle I and rises to 91 in cycle II. The conclusion of this research is that the technical assistance with the SP3R pattern is very effective and can improve the teacher's ability to arrange questions.

Key words: ability to write questions, teachers, mentoring with SP3R patterns.

PP No. 32 Tahun 2013 tentang standar nasional pendidikan ayat 3 menyatakan bahwa setiap satuan pendidikan melakukan perencanaan proses pembelajaran, pelaksanaan proses pembelajaran, penilaian hasil pembelajaran, dan pengawasan proses pembelajaran untuk terlaksananya proses Pembelajaran yang efektif dan efisien. Pernyataan di atas mengisyaratkan bahwa pembelajaran yang efektif dan efisien menjadi syarat utama keberhasilan pencapaian tujuan pendidikan. Untuk mewujudkan efektifitas dan efisiensi pembelajaran, maka empat komponen tersebut harus dilaksanakan secara konsisten.

Dari empat standar tersebut, penilaian merupakan satu-satunya alat utama untuk mengetahui apakah pembelajaran telah berjalan secara efektif atau belum. Tim Depdiknas (2004) mengemukakan bahwa penilaian merupakan serangkaian kegiatan untuk memperoleh, menganalisis, dan menafsirkan data tentang proses dan hasil belajar siswa yang dilakukan secara sistematis dan berkesinambungan, sehingga 
menjadi informasi yang bermakna dalam pengambilan keputusan.

Menurut (Zainul \& Nasution, 2001), penilaian atau evaluasi dapat dinyatakan sebagai suatu proses pengambilan keputusan dengan menggunakan informasi yang diperoleh melalui pengukuran hasil belajar, baik yang menggunakan instrumen tes maupun non tes. Sementara (Arikunto, 2000) memberikan pengertian bahwa evaluasi adalah serangkaian kegiatan yang ditujukan untuk mengukur keberhasilan program pendidikan.

Sejak diberlakukannya kurikulum 2013, penilaian dalam proses pembelajaran ditekankan pada pelaksanaan penilaian secara otentik. Penilaian otentik adalah proses pengumpulan informasi oleh guru tentang perkembangan dan pencapaian pembelajaran yang dilakukan oleh peserta didik melalui berbagai teknik yang mampu mengungkapkan, membuktikan atau menunjukkan secara tepat bahwa tujuan pembelajaran telah benar-benar dikuasai dan dicapai. Guru sering tidak menyadari penilaian yang dilakukan dengan tujuan pembelajaran dan proses pembelajaran. (Anggraeni, 2016)

Penilaian otentik bertujuan untuk mengevaluasi kemampuan siswa dalam konteks dunia nyata. Dengan kata lain, siswa belajar bagaimana mengaplikasikan pengetahuan dan keterampilannya ke dalam tugas-tugas yang autentik. Melalui penilaian autentik ini, diharapkan berbagai informasi yang absah/benar dan akurat dapat terjaring berkaitan dengan apa yang benar-benar diketahui dan dapat dilakukan oleh siswa atau tentang kualitas program pendidikan. Agar penilaian otentik berjalan dengan baik, guru harus memahami secara jelas tujuanpenilaian yang ingin dicapai. Oleh karena itu, penting bagi guru untukmemahami : (1) sikap, keterampilan, dan pengetahuan apa yang akan dinilai; (2) fokus penilaian mana akan dilakukan, misalnya, berkaitan dengan sikap, keterampilan, dan pengetahuan; (3) tingkat pengetahuan apa yang akan dinilai, seperti penalaran, memori, atau proses.

Metode dan alat berperan sebagai alat pembantu untuk memudahkan guru dalam mengajar dan murid dalam belajar. Sedangkan penilain berguna untuk mengetahui sejauh mana murid telah mengalami proses pembelajaran yang ditujukan oleh perubahan perilakunya (Fatmayanis, 2012)

Dalam melaksanakan penilaian guru hendaknya benar-benar memahami fungsi penilaian itu sendiri. (Marimin, 2017) mengemukakan beberapa hal terkait fungsi penilaian atau evaluasi: (1) Evaluasi merupakan alat yang penting sebagai umpan balik bagi siswa. Melalui evaluasi, siswa akan mendapatkan informasi tentang aktivitas pembelajaran yang dilakukan. Dari hasil evaluasi siswa akan dapat menentukan harus bagaimana proses pembelajaran yang perlu dilakukan. (2) Evaluasi merupakan alat yang penting untuk mengetahui bagaimana ketercapaian siswa dalam menguasai tujuan yang telah ditentukan. Siswa akan tahu bagaian mana yang perlu di pelajarai lagi dan bagian mana yang tidak perlu. (3) Evaluasi dapat memberikan informasi untuk mengembangkan program kurikulum. Informasi ini sangat dibutuhkan baik untuk guru maupun untuk para pengembang kurikulum khususnya untuk perbaikan program selanjutnya. (4) Informasi dari hasil evaluasi dapat digunakan oleh siswa secara individual dalam mengambil keputusan, khususnya untuk menentukan masa depan sehubungan dengan bidang pekerjaan serta pengembangan karir. (5) Evaluasi berguna untuk para pengembang kurikulum khususnya dalam menentukan kejelasan tujuan khusus yang ingin dicapai. Misalnya apakah tujuan itu mesti dikurangi atau ditambah. (6) Evaluasi berfungsi sebagai umpan balik untuk semua pihak yang tua, untuk guru dan pengembang kurikulum, untuk perguruan tinggi, pemakai lulusan, untuk orang yang mengambil kebijakan pendidikan termasuk juga untuk masyarakat. Melalui evaluasi dapat dijadikan bahan informasi tentang efektivitas program pembelajaran sekolah. (Sulaiman, 2015)

Sebuah alat evaluasi memiliki syarat kelayakan sebelum diberikan ke peserta didik. (Sukardi, 2008) mengemukakan bahwa, suatu evaluasi memenuhi syaratsyarat sebelum diterapkan kepada siswa yang kemudian direfleksikan dalam bentuk tingkah laku. Evaluasi yang baik, harus mempunyai syarat seperti berikut: (1) valid, (2) andal, (3) objektif, (4) seimbang, (5) membedakan, (6) norma, (7) fair, dan (8) 
praktis. Sedangkan Wina Sanjaya (2008), mengatakan bahwa syarat-syarat alat evaluasi yang baik harus memenuhi kriteria: (1) Memberikan motivasi, (2) Validitas, (3) Adil, (4) Terbuka, (5) Berkesinambungan, (6) Bermakna, (7) Menyeluruh, dan (8) Edukatif

Di dalam Permendikbud No. 23 Tahun 2016 ditegaskan bahwa penilaian pengetahuan hendaknya dilakukan melalui prosedur. Salah satu tahapan dari prosedur penilaian adalah mengembangkan instrument penilaian. Menurut Dirjen Dikdasmen Kemdikbud dalam Panduan Penilaian untuk sekolah dasar (2016). Instrumen penilaian adalah alat yang disusun dan digunakan untuk mengumpulkan dan mengolah informasi untuk mengukur pencapaian hasil belajar peserta didik. Instrumen yang baik adalah instrument yang penyusunannya sesuai kaidah. Sebagaimana kita ketahui bahwa instrument penilaian yang baik memiliki ciriciri dan harus memenuhi beberapa kaidah antara lain: Validitas, Reliabilitas, Objectivitas, Pratikabilitas, Ekomonis, Taraf Kesukaran, dan Daya Pembeda. Validitas berasal dari kata validity yang mempunyai arti sejauh mana ketepatan dan kecermatan suatu alat ukur dalam melakukan fungsi ukurnya. Menurut Kamus Besar Bahasa Indonesia bahwa Validitas diartikan sebagai sifat benar, menurut bukti yang ada, logika berfikir, atau kekuatan hukum. Dengan demikian dapat dikatakan bahwa instrument penilaian dikatakan valid jika dapat mampu menjalankan fungsinya secara tepat berdasarkan bukti, logika, dan kekuatan hukum yang ada. Reliabilitas mengandung arti bahwa Instrumen penilaian dikatakan memiliki reliabilitas yang tinggi manakala instrumen tersebut mampu menghasilkan informasi yang ajeg. Keajegan ini mengandung arti bahwa dimanapun instrument ini digunakan akan menghasilkan informasi yang sama tentang kemampuan antara individu satu dengan yang lain. Objectivitas mengandung makna bahwa instrument yang disusun terbebas dari pengaruh-pengaruh pribadi penilai. Praktikabilitas mengandung arti bahwa intrumen yang dibuat harus mudah dilakukan secara praktik maupun pengadministrasian. Ekonomis mengandung pengertian bahwa penggunaan instrument dapat dilakukan dengan biaya yang sangat minim dan tidak membutuhkan waktu lama. Taraf Kesukaran, mengandung arti bahwa instrumen penilaian dikatakan baik jika butir-butir instrument yang dibuat tidak terlalu mudah dan tidak terlalu sukar bagi pesertadidik. Daya Pembeda, mengandung arti maksud bahwa instrument yang disusun hendaknya mampu membedakan antara peserta didik yang pandai (berkemampuan tinggi) dengan peserta didik yang tidak pandai (berkemampuan rendah).

Berkaitan dengan Standar Penilaian, secara rinci pada buku Instrument Mutu Sekolah ditegaskan bahwa kendala guru dalam penilaian adalah guru belum melakukan penilaian sesuai prosedur yang ditentukan. Pada bagian ditemukan bahwa pemahaman pendidik terhadap proses penilaian masih belum maksimal. Sekolah juga belum mampu mengembangkan perangkat penilaian secara mandiri. Untuk itu pemerintah telah mengintegrasikan materi penilaian dalam setiap kegiatan BIMTEK yang dilakukan. Sejalan dengan upaya tersebut pemerintah juga mendorong pengawas sekolah untuk giat melakukan pembinaan ke sekolah binaan, untuk memastikan guru-guru tidak mengalami kendala dalam menyusun instrument penilaian. Pemerintah melalui permendiknas no 12 Tahun 2007 menegaskan bahwa salah satu tugas pengawas dalam penilaian adalah membina guru dalam memanfaatkan hasilpenilaian untuk perbaikan mutu pendidikandan pembelajaran/bimbingan tiap bidang pengembangan di TK/RA atau mata pelajaran di SD/MI. Demikian juga dengan kepala sekolah, dalam permendiknas No. 19 Tahun 2007 ditegaskan bahwa salah satu tugas kepala sekolah adalah mengevaluasi pendayagunaan pendidik dan tenaga kependidikan. Dengan demikian sudah menjadi tugas kepala sekolah untuk melakukan pembimbingan terhadap guru termasuk Dengan demikian kepala sekolah juga memiliki peran yang sangat penting dalam membina guru termasuk membimbing guru dalam menyusun perangkat penilaian. Fakta di lapangan sebagian besar guru masih mengalami kendala dalam menyusun soal.Berdasarkan hasil supervisi perangkat pembelajaran Dari 8 guru setelah dilakukan pengamatan terhadap instrument soal tes tulis didapat informasi bahwa mayoritas soal yang ditulis masih jauh dari kaidah 
penyusunan soal yang baik. Tiga aspek yang menjadi sasaran pengamatan terhadap soal tes yang disusun guru yaitu aspek materi soal, konstruksi, dan bahasa, dengan kriteria bahwa guru dianggap memiliki kemampuan dalam menyusun soal jikanilai rata-rata ketiga aspek minimal mencapai 80. Gambaran kesenjangan dibuktikan dengan kondisi nilai rata-rata tiap aspek dimana hasil capaian pada aspek materi dengan nilai rata-rata 63 , aspek konstruksi nilai rata-rata 70 , dan aspek bahasa yang hanya mampu mencapai nilai 68 .

Dari data didapat informasi kelemahan guru dalam menyusun soal adalah: dari aspek materi ditemukan banyak soal yang materinya tidak dipelajari sisiwa, soal yang ditulis juga guru tidak sesuai dengan indikator. Dari aspek konstruksi didapati permasalahan rumusan pokok soal yang terlalu panjang dan sulit dipahami, soal memuat kata yang dapat menimbulkan penafsiran ganda, pengecoh banyak yang tidak berfungsi terutama pada soal matematika. Dari aspek bahasa banyak ditemukan soal yang bahasanya kurang dapat dipahami, membingungkan siswa dalam menjawab, dan bahasa yang digunakan kurang mengedepankan penggunaan bahasa yang baik dan benar.

Pada kondisi ini kepala sekolah selaku pengendali utama pegelolaan sekolah berkewajiban untuk memastikan standar mutu penilaian tetap terjaga.Peraturan Menteri Pendidikan Nasional No. 19 Tahun 2007 tentang Standar Pengelolaan, yang dijabarkan dalam bentuk instrument supervisi mutu menjelaskan bahwa salah satu penyebab tidak tercapainya mutu adalah Kepala sekolah kurang mampu menjalankan tugas kepemimpinan.

$$
\text { Kepala sekolah memandang }
$$
permasalahan yang dialami guru sangat serius sehingga perlu dicarikan solusi.Hasil analisis berbagai penyebab terjadinya masalah tersebut yaitu masih kurangnya kesadaran diri guru atas kesalahan yang dilakukan. Kurangnya komunikasi yang membahas secara khusus tentang teknik penulisan soal. Guru juga kurang terbiasa atau kurang terlatih dalam menyusun soal, kepala sekolah juga jarang melakukan konfirmasi secara detai produk soal tulisan guru. Untuk mengatasi permasalahan tersebut, peneliti membuat konsep kegiatan dengan metode pendampingan dengan pola SP3R. Salah satu indikator yang menunjukkan bahwa seorang guru tersebut mampu menyusun tes telah banyak dilakukan seperti mengikuti penataran dan pelatihan lainnya(Osnal, O., Suhartoni, S., \& Wahyudi, 2015)

$\mathrm{SP}_{3} \mathrm{R}$ adalah kependekan dari Self assesment, pre evaluation, practice, post evaluation, and reward.(Rusman, 2013) Pola ini memungkinkan guru untuk mengembangkan soal tes tulis melalui empat tahapan pokok. Self assessment merupakan kegiatan dimana guru dikondisikan pada situasi bagaimana mereka mengetahui sendiri kelemahan soal tes tulisnya. Penerapan kegiatan self assessment yang menuntut keikutsertaan aktif guru dalam menegidentifikasi yang sekaligus membutuhkan kesungguhan dan ketelitian. Jika semua guru memiliki kesungguhan dan ketelitian akan menghasilkan kualitas soal yang optimal. Segera setelah melakukan aktivitas pre evaluation, guru bersama kepala sekolah melakukan dialog/diskusi membahas berbagai pertanyaan terkait pemahaman dalam mengembangkan soal tes. Menurut (Sujiono, 1996) Pretest atau tes awal yaitu tes yang dilaksanakan dengan tujuan untuk mengetahui sejauh manakah materi atau bahan pelajaran yang akan diajarkan telah dapat dikuasai oleh siswa" Kegiatan selanjutnya yang harus dilakukan guru adalah praktik membuat sial tes sesuai tugas masing-masing (practice). Praktik menyusun soal akan memberikan banyak pengalaman pada guru dalam mengembangkan soal.(Mulatu \& Bezabih, 2018) Semakin banyak soal yang dibuat guru maka semakin banyak pengalaman yang dimilii guru, sehingga dalam pengembangan soal berikutnya tidak akan mengalami banyak kendala. Tahap berikutnya yang harus dilakukan guru adalah post evaluation. Pada tahap ini kepala sekolah dan guru saling menilai soal yang telah dibuat guru sekaligus dilakukan penyekoran. Pre-test dan Post-test dapat dijadikan "Pengatur kemajuan (belajar)" (Advance Organizations) Menurut Asubel dalam (Prasetya Irawan, 2001) Mahasiswa akan belajar dengan baik jika apa yang disebut dengan Advance Organizations didefenisikan dan dipresentasikan dengan baik." 


\section{METODE}

Subyek penelitian ini adalah guru-guru di SDN Sepanyul Kecamatan Gudo Kabupaten Jombang, Penelitian dilaksanakan selama 3 bulan mulai Februari hingga April 2018. Penelitian ini menggunakan alur penelitian rancangan model Kemmis yang terdiri atas empat langkah, yakni: perencanaan, pelaksanaan, observasi dan refleksi (Azal, 2018) Pemilihan model didasarkan pada efektifitas penelitian dengan alur sebagaimana gambar berikut.

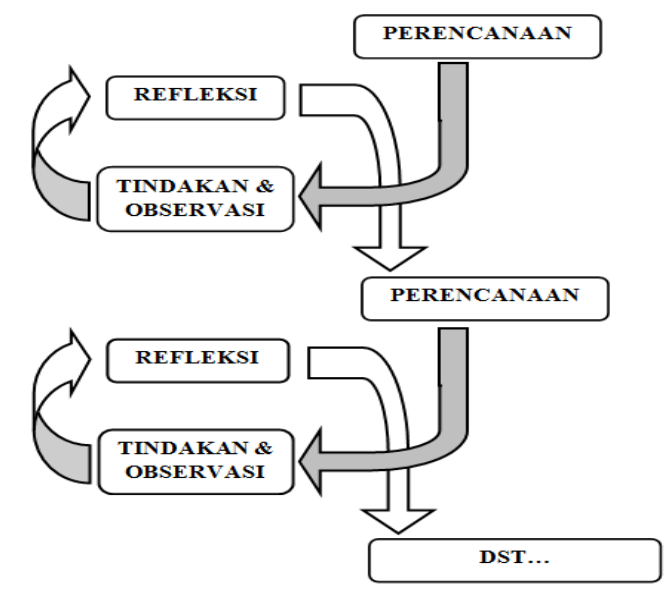

Gambar 1: Diagram alur penelitian

Dalam pengimplementasian alur penelitian Kemmis di atas, peneliti mengintegrasikan kegiatan pendampingan pola $\mathrm{SP}_{3} \mathrm{R}$ pada tahap pelaksanaan dan menjadi sebuah sistem mandiri terintegrasi. Aktifitas lebih menekankan kemampuan guru dalam mendeteksi kesalahan diri, memperbaiki kesalahan, dan mengembangkan soal sesuai kaidah. $\mathrm{SP}_{3} \mathrm{R}$ dilakukan dalam 5 tahapan meliputi 4 tahap pokok (self assessment, pre evaluation, practice,post evaluation) dan 1 tahap tambahan (reward). Kelima tahapan tersebut jika dibuat desain sebagai berikut.

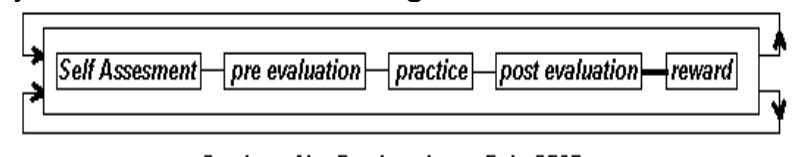

Gambar : Alur Pendampingan Pola SP3R

Data dan sumber data pada penelitian ini diperoleh dari hasil pengamatan soal buatan guru menggunakan instrument telaah soal.Pengumpulan data dilakukan dengan teknik skoring pada setiap butir soal dan diolah menjadi data individu, Selanjutnya data dikumpulkan untuk dianalisis.Kegiatan analisis datadilakukan dengan tahapan koleksi data, reduksi data, penyajian data,(Moleong, 2014) dan yang terakhir adalah penarikan kesimpulan. Kesimpulan diambil dengan membandingkan capaian setelah perlakukan dengan data awal (sebelum tindakan) kemudian membandingkan dengan kriteria nilai.Pengolahan hasil telaah tes tulis menggunakan dua rumus meliputi rumus nilai akhir guru dan rumus nilai kelompok atau lembaga. Nilai akhir guru diolah dengan rumus:

$$
\mathrm{NAG}=\frac{\mathrm{RM}+\mathrm{RK}+\mathrm{RB}}{3} \times 100
$$
Keterangan:
NAG : Nilai Akhir Guru
RM : Nilai Rata-rata Aspek Materi
RK : Nilai Rata-rata Aspek
RB : Nilai Rata-rata Aspek
Bahasa

Sedangkan nilai rata-rata kemampuan guru dalam satu lembaga dihitung dengan rumus:

$$
N A=\frac{N A G 1+N A G 2+\ldots .+N A G 8}{8}
$$

Keterangan:

$\begin{array}{ll}\text { NA } & \begin{array}{l}\text { : Rata-rata nilai akhir guru } \\ \text { dalam satu lembaga }\end{array} \\ \text { NAG } 1 & \text { : Nilai Akhir Guru ke-1 } \\ \text { NAG } 2 & \text { : Nilai Akhir Guru ke-2 } \\ \text { NAG ke-3 } & \text { s.d. NAG ke-7 } \\ \text { NAG } 8 & \text { : Nilai Akhir Guru ke-8 }\end{array}$

\section{HASIL DAN PEMBAHASAN}

SIKLUS I

Penelitian berawal dari pengamatan terhadap soal tes tulis guru yang didapat informasi bahwa soal buatan guru-guru masih berada di bawah standar/kaidah penyusunan soal dengan kriteria yang ditetapkan. Dengan subyek penelitian orang yang dewasa dengan kepercayaan diri yang tinggi tentu sangatlah sulit bagi peneliti untuk membenahi secara langsung, sehingga perlu langkah sistematis agar guru mampu menyadari dan bertindak berdasarkan kekurangan melalui kegiatan self 
assessment. Pada tahap ini diharapkan guru menyadari kemampuan dirinya dalam menyusun soal. Setelah menyadari kekurangan dan kelebihan, guru dibawa ke kondisi ideal melalui kegiatan pre assessment dimana guru diajak mengkaji hasil assessment-nya untuk didiskusikan dengan kepala sekolah. Pada kegiatan selanjunya, manakala guru sudah memiliki persepsi sama tentang kaidah penulisan soal, maka guru diminta menyusun sebuah peragkat tes sesuai kaidah. Hasil karya guru kemudian dinilai sebagai bentuk pemantauan peningkatan yang telah dicapai.Sebagai langkah akhir, reward of reflection, mengandung makna pemberian penghargaan setelah refleksi.(Sugiyono, 2008)

Gambaran hasil kegiatan pendampingan berpola SP3R dalam meningkatkan kemampuan guru dalam menyusun soal adalah sebagai berikut. Pada tahap self assesment atau dalam Bahasa Indonesianya penilaian secara mandiri, peneliti membagikan instrumen kegiatan meliputi kisi-kisi soal, dan pedoman observasi. Guru diminta mengamati dan menilai sendiri soal yang telah dibuat dengan berpedoman pada kisi-kisi dan instrument yang diberikan. Guru diminta menilai soalnya secara jujur dan apa adanya dan diminta merefleksi kelemahan soal yang dibuat. Pada tahap ini didapat informasi kebanyakan guru mengalami kendala pemahaman terhadap pemilihan materi, konstruksi, dan penggunaan bahasa. Pada tahap Pre evaluation guru dan kepala sekolah saling tukar pikiran membahas hasil evaluasi mandiri guru. Kepala sekolah memberi masukan perbaikan atas permasalahan yang dihadapi guru. Informasi yang didapat setelah diskusi berlangsung adalah guru memang belum terbiasa menyusun soal menggunakan kisi-kisi. Guru juga menyampaikan bahwa soal yang ditulis selama ini belum pernah dianalisa atau direvisi sehingga tidak tahu dimana salahnya. Terhadap temuan ini kepala sekolah berusaha memotivasi guru dan membimbing menganalisa soal secara teliti sesuai indikator atau kaidah penulisan yang benar. Dari sini guru sudah mengalami peningkatan pemahaman sehingga pada kegiatan penyusunan soal sudah sedikit sekali mengalami kendala. Setelah guru memahami materi kaidah penulisan soal dibawa masuk ke tahap praktik (practice). Pada kegiatan ini kepala sekolah tetap memberi petunjuk dan arahan agar soal tersusun dengan baik. Tahapan berikutnya post evaluation dimana kepala sekolah menilai soal yang telah ditulis guru.Hasil penilaian setelah perlakuan ditunjukkan pada grafik

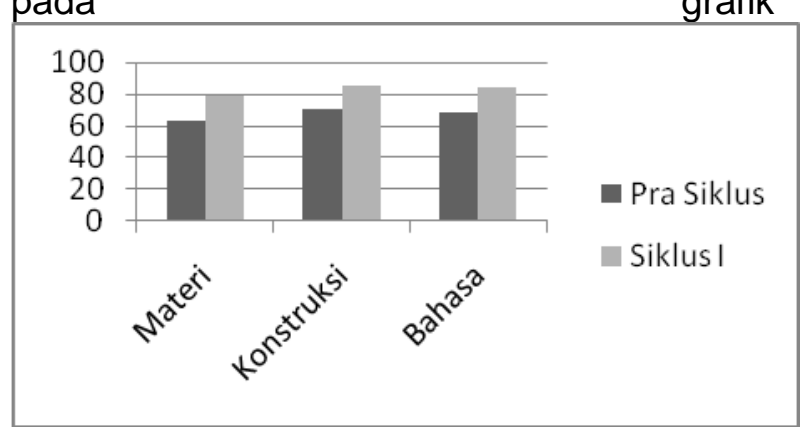

Diagram menunjukkan adanya peningkatan kualitas soal yang disusun guru dimana pada aspek materi soal nilai ratarata mencapai 79 , mengalami peningkatan 16 angkadibanding sebelum tindakan. Pada aspek konstruksi soal juga mengalami perkembangan signifikan dimana sebelum tidakan nilai rata-rata berada pada 70 menjadi 85 atau naik 15 angkadibanding sebelum tindakan. Peningkatan juga terjadi pada rata-rata nilai kemampuan penggunaan bahasa dimana sebelum tindakan rata-rata nilai yang hanya mencapai 68 menjadi 84 atau mengalami peningkatan sebesar 16 angka.Dari gambaran tersebut tampak bahwa kualitas soal yang dibuat guru makin baik, ini membuktikan bahwa kemampuan guru dalam menyusun soal juga semakin baik. Jika melihat data capaian secara umum terjadi peningkatan signifikan pada ketiga aspek dibanding sebelum tindakan, akan tetapi pada satu aspek yaitu materi masih perlu peningkatan. Kondisi ini memantik kepala sekolah untuk menentukan langkah selanjutnya guna memperbaiki kekurangan pada tindakan siklus I dan menuangkannya pada tindakan siklus II.

Tahap berikutnya adalah pemberian reward. (Hazraini, 2017) menyatakan bahwa Pemberian reward merupakan tanda bahwa Anda menghargai kinerja karyawan. Reward dapat mendorong karyawan agar bekerja lebih giat dan memberikan kontribusi yang lebih besar bagi perusahaan. Lebih jauh dikatakan bahwa reward tidak melulu harus berupa uang. Kita bisa menunjukkan apresiasi dengan berbagai cara. 
Pada tahap ini kepala sekolah kembali mengajak semua guru untuk melakukan refleksi dan mengucapkan terimakasih, memberi penghargaan setinggi-tingginya atas makin meningkatnya kualitas soal buatan guru-guru dan mengajak untuk meningkatkan lagi kemampuan pada aspek yang masih perlu peningkatan yaitu pada aspek materi.

Hasil refleksi pada siklus I adalah: (a) dari sisi efektifitas, melalui instrument evaluasi diri bahwa guru merasa antusias dan senang dengan kegiatan yang dilakukan dibuktikan dengan tingkat kehadiran pada presensi $100 \%$ pada setiap kegiatannya. Guru juga merasa punya ruang untuk menggali kekurangannya dalam mengembangkan soal tes tulis. Guru juga merasa terbantu dengan adanya kegiatan ini. Guru juga merasa bahwa kegiatan ini tepat dan sesuai dengan kebutuhan. Terdapat sedikit kekurangan pada sisi efektifitas yaitu terdapat kemungkinan subyektifitas guru dalam menilai kemampuan diri pada saat self assessment dimana penilaian terhadap diri sendiri terdapat indikasi kurang tepat sehingga perlu perbaikan langkah pada siklus berikutnya. (2) Dari sisi signifikansi, dari tiga aspek yang dinilai masih terdapat satu aspek di bawah kriteria yaitu aspek materi. Guru masih mengalami kendala dalam menuangkan indikator soal ke wujudnya sehingga masih banyak ditemukan soal yang secara konteks mengalami penyimpangan, misalnya: pada kisi-kisi, indikator soal berbunyi "Disajikan teks narasi ...."tetapi pada soal yang ditulis teks deskripsi. Contoh lain adalah, indikator soal berbunyi "Disajikan dialog dua orang siswa dapat ...." Tetapi dalam soal disajikan teks drama.Pada pandangan peneliti hal ini terjadi karena masih belum maksimalnya pemahaman guru terhadap indikator soal. Oleh karena itu pada siklus II perlu dilakukan penambahan materi khusus tentang bagaimana membedah indikator soal. Dengan demikian terdapat dua hal pokok yang perlu mendapat perhatian pada siklus II yaitu subyektifitas dan kemampuan menuangkan indikator dalam soal.

\section{SIKLUS II:}

Sebagaimana siklus sebelumnya, tahap self assessment dilakukan dengan cara meminta guru mengamati dan menelaah soal-soal yang dibuat pada siklus I, akan tetapi mekanismenya sedikit diubah dimana guru melakukan assessment silang dalam kerangka tim. Guru diberi soal beserta instrument dan kisi-kisi soal. Seperti biasanya guru diminta menilai soal yang dipegang secara jujur dan apa adanya dan diminta merefleksi kelemahannya. Pada tahapan ini didapat informasi yang tidak jauh dari kondisi akhir saat siklus I dilaksanakan, dimana rata-rata masih terdapat kekurangan pada penulisan materi soal. Pada tahap pre evaluation dilakukan dengan diskusi kolaborasi, menyikapi kelemahan pada kegiatan sebelumnya. Pada tahap ini guru diminta menyampaikan kendala dalam penyusunan soal terutama yang berkaitan dengan aspek materi.Kepala sekolah selaku peneliti mendapati hal penting yang perlu ditindaklanjuti segera yaitu masih terdapat kesalahan guru dalam memahami indikator soal. Guru masih mengalami kendala menafsirkan indikator sehingga beberapa soal masih belum memenuhi kriteria. Pada tahap pre evaluation kepala sekolah memberikan penjelasan beberapa hal terkait dengan indikator soal meliputi: memahamkan konsep stem soal, mengkaji indikator dan menghubungkannya dengan level soal,cara mengembangkan stimulus soal, cara mengembangkan pengecoh soal yang baik, dan sebagainya. Sedangkan pada tahap Practice guru diminta mengeksplorasi kemampuannya dalam menyusun soal. Pada pelaksanaannya guru menyusun soal dan kepala sekolah tetap mendampingi untuk memberikan penjelasan manakala guru mengalami permasalahan pada aspek-aspek tertentu. Hasil pengamatan pada pelaksanaan tahap ini, guru lebih cepat dari sebelumnya dalam menyelesaikan tugas penyusunan soal. Pertanyaan juga tidak terlalu banyak bahkan hampir tidak ada pertanyaan yang berarti terkait kaidah penyusunan soal.Peneliti berasumsi bahwa kondisi yang terjadi merupakan pertanda adanya kemajuan yang signifikan terkait kemampuan guru dalam menyusun soal.Ini juga menandakan bahwa penerapan teknik pendapingan membawa dampak yang lebih baik. Pada tahap Post evaluation, kepala sekolah menelaah soal yang telah dibuat guru dan memberi skor dan selanjutnya diberi nilai. Secara 
berurutan kegiatan pra siklus, siklus I, dan siklus II hasilnya sebagaiberikut.

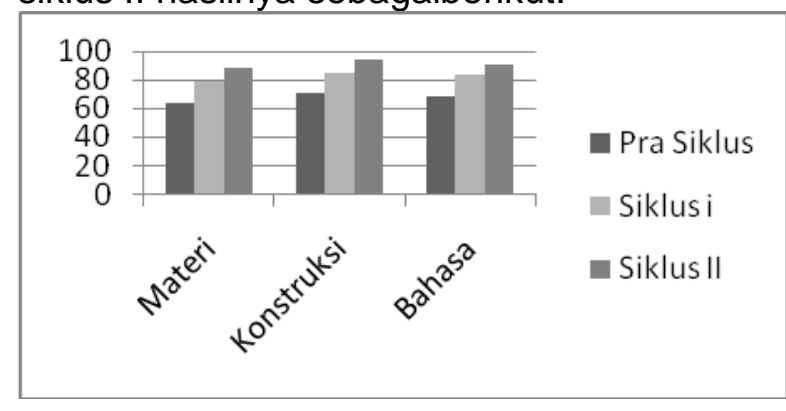

Diagram menggambarkan capaian nilai kemampuan guru dalam menyusun soal tes meliputi aspek materi, konstruksi, dan bahasa mulai dari pra siklus, siklus I, hingga siklus III, dengan deskripsi sebagai berikut. Terjadi peningkatan nilai pada aspek materi, dimana pada pra siklus hanya berada pada angka 63 pada siklus I naik menjadi 79 dan meningkat menjadi 88 pada siklus II. Pada kemampuan mengkonstruksi soal juga mengalami peningkatan dimana pada pra siklus nilai konstruksi hanya berada pada angka 70 naik menjadi 85 pada siklus I dan menjadi 94 pada siklus II. Pada aspek penggunaan bahasa juga terjadi peningkatan, dimana pada pra siklus nilainya hanya mencapai 68 , menjadi 84 pada siklus I, dan naik menjadi 90 pada siklus II.

Data di atas memberikan gambaran bahwa kemampuan guru dalam menyusun soal telah mengalami peningkatan yang signifikan. Peningkatan nilai pada aspek materi didukung kondisi dimana materi yang dipilih benar-benar telah dipelajari oleh siswa, sebagian besar guru juga sudah memahami cara mengimplentasikan indikator soal ke dalam wujud soal, ini disebabkan karena telah dilakukan kegiatan memahami konsep sistem soal, mengkaji indikator dan menghubungkannya dengan level soal, cara mengembangkan stimulus soal, cara mengembangkan pengecoh soal yang baik sebagaimana dilakukan pada tahap pre evaluation. Penigkatan nilai pada aspek konstruksi didukung oleh peningkatan kemampuan guru dalam merumuskan soal dimana soal-soal sudah ditulis dengan kalimat yang singkat dan jelas. Pokok soal tidak menampakkan gejala adanya penafsiran ganda, butir-butir soal yang ditulis tidak menunjukkan adanya ketergantungan dengan jawaban soal lain. Peningkatan yang lain adalah cara penulisan option dan pengecoh yang benar-benar berfungsi. Peningkatan pada aspek bahasa lebih didongkrak oleh adanya peningkatan beberapa indikator antara lain, penggunaan kalimat dan kata sangat komunikatif dan mudah dipahami, cara merumuskan soal juga bersifat umum artinya tidak ada yang menunjukkan unsur menyinggung perasaan orang lain atau sara, bahasa soal juga jelas dan mudah dimengerti, bahasa yang digunakan juga bahasa yang baik dan benar, artinya bahasa yang digunakan sudah sesuai dengan kaidah. Pada tahap Reward, sebagai symbol semangat dan otivasi kepala sekolah mengajak guru-guru untuk pergi ke suatu tempat melakukan refreshing sekaligus ungkapan terimakasih atas kemajuan luar biasa yang telah dialami bersama.

Hasil penelitian secara umum adalah setelah dilakukan kegiatan pendampingan berpola SP3R, kemampuan guru dalam menyusun soal mengalami peningkatan, dimana sebelum tindakan kualitas soal berada pada nilai 67 . Setelah dilakukan tindakan pendampingan berpola SP3R siklus I nilainya mencapai 83 dan meningkat 91 pada siklus II. Jika dibandingkan kondisi sebelum tindakan dengan sesudah tindakan, maka terjadi peningkatan sebesar 24 angka atau mengalami peningkatan sebesar $35 \%$.

\section{KESIMPULAN}

Berdasarkan efektifitas kegiatan dan hasil pengolahan data setelah tindakan pada penelitian dapat dikemukakan kesimpulan bahwa: (1) Pelaksanaan pendampingan berpola SP3R untuk meningkatkan kemampuan guru dalam menyusun soal terbukti sangat efektif. (2) Pelaksanaan pendampingan berpola SP3R mampu meningkatkan kemampuan guru dalam menyusun soal. Kompetensi guru menyusun instrumen tes adalah pengetahuan, kemampuan dan keterampilan yang harus dimiliki oleh guru untuk menyusun alat yang digunakan untuk mengukur kemampuan peserta didik setelah melakukan proses belajar mengajar melalui kegiatan penilaian (Sijabat, 2014)

\section{SARAN}

Atas permasalahan dan solusi penelitian di atas dapat dikemukakan beberapa saran khususnya kepada guru dan pihak terkait: 
(1) Segala permasalahan hendaknya diselesaikan secara demokratis dan terbuka.

(2) Upayakan senantiasa intropeksi atas kekurangan diri dan selalu berusaha belajar.

(3) Perlu dilakukan kegiatan/penelitian serupa terhadap permasalahan guru yang lain. (4) Ilmu yang sudah diperoleh hendaknya terus digunakan agar semakin membuat kita terampil.

\section{DAFTAR RUJUKAN}

Anggraeni, L. (2016). Peningkatan Kompetensi Guru Menyusu Butir Soal Bermutu Melalui Program Workshop. Jurnal Inovasi Pembelajaran Karakter (JIPK), 1(2), 1-9.

Arikunto, S. (2000). Manajemen Kurikulum. Yogyakarta.

Azal, A. Q. (2018). Peningkatan Kompetensi Guru SMPN 3 Pademawu Dalam Menyusun Instrumen Penilaian Autentik Melalui Workshop. Wacana Didaktika, 6(01), 27-40.

https://doi.org/10.31102/wacanadidaktik a.6.01.27-40

Fatmayanis. (2012). Kemampuan guru-guru sejarah smk dalam menyusun dan menganalisis soal. Jurnal Manajer Pendidikan, 10(5), 464-468.

Hazraini. (2017). Upaya Meningkatkan Kompetensi Guru Kelas Dalam Penyusunan Soal Pilihan Ganda Yang Baik dan Benar Melalui Pendampingan Berbasis KKG Semester Satu Tahun Pelajaran 2017/2018 di SD Negeri 30 Cakranegara. Jurnal Jupe, 10(2), 1-15.

Marimin, M. (2017). Upaya Meningkatkan Kemampuan Guru dalam Menyusun Tes Hasil Belajar Akhir Semester I melalui Supervisi Akademik Pada Kelas V Dabin II Pattimura Kecamatan Jatiyoso Tahun Pelajaran. Jurnal IImiah Mitra Swara Ganesha, 4(1), 37-57.

Moleong, J. (2014). Lexy, Metodologi Penelitian kualitatif, Penerbit PT. Remaja Rosdakarya Bandung.

Mulatu, M., \& Bezabih, W. (2018). Perceptions and practices of EFL teachers in implementing active learning in English classes: the case of three selected secondary schools in Dawro zone, SNNPRS, Ethiopia. International Journal of Education, 10(2).

Osnal, O., Suhartoni, S., \& Wahyudi, I.
(2015). Meningkatkan Kemampuan Guru dalam Menyusun Tes Hasil Belajar Akhir Semester melalui Workshop di KKG Gugus 02 Kecamatan Sumbermalang Tahun 2014/2015. Pancaran Pendidikan, 5(1), 67-82.

Prasetya Irawan, S. (2001). Teori Belajar dan Motivasi. Jakarta: Universitas Terbuka.

Rusman, D. (2013). Pembelajaran Berbasis Teknologi Informasi dan Komunikasi: Mengembangkan Profesionalitas Guru. Jakarta: Raja Grafindo Persada.

Sijabat, L. (2014). Meningkatkan Kompetensi Guru Menyusun Instrumen Tes Melalui Model Pelatihan SSOTT. Jurnal Pendidikan Dan Kepengawasan, 1(1), 107-118.

Sugiyono, P. D. (2008). Metode penelitian kuantitatif dan kualitatif dan R\&D. Bandung (ID): Alfabeta.

Sujiono, A. (1996). Pengantar Evaluasi Pendidikan. Jakarta: PT Raja Grafindo Persada.

Sukardi. (2008). Evaluasi Pendidikan (B. Aksara, ed.). Yogyakarta.

Sulaiman. (2015). Classroom Management and The Implications to Quality of Learning (A Study About Classroom Climate at Madrasah Aliyah in Aceh, Indonesia. Jurnal IImiah Peuradeun, 3(3).

Zainul, \& Nasution. (2001). Penilaian Hasil Belajar. Jakarta: Dirjen Dikti. 